\title{
Teaching and Learning as a Way of Life
}

\section{PÁDRAIG HOGAN}

This essay seeks to show that teaching and learning are to be properly understood, not as an undertaking carried out on the will of a higher power or party, but as a way of life with an integrity of its own, arising from its own integral purposes. The essay thus seeks to provide an understanding of educational practice and of educational thought that contrasts in key respects with Alasdair MacIntyre's understanding, though also with a some notable parallels. A largely forgotten 'Socrates of Athens' is identified as furnishing the original inspiration for the understanding of education explored in the essay. Some influential modern (and postmodern) negations of this understanding are then reviewed. Arising from its investigation of teaching and learning as a singular kind of relationship, the essay concludes with a brief sketch of some virtues that might constitute the way of life in question, in its more active and its more reflective moments.

\section{INTRODUCTION}

Historical studies of Western education show that teaching as an occupation has rarely enough enjoyed the freedom to conduct its affairs in accordance with its practitioners' views on how the best interests of learning are to be understood and advanced. ${ }^{1}$ Thus, after many centuries of patriarchal control of teaching and learning, the advent of the liberal university in early nineteenth-century Germany signalled a breakthrough for what has come to be known as the Enlightenment ideal of academic freedom. This ideal-which in truth has an ancestry more ancient than the European Enlightenment - has until recently had a major impact on higher education internationally. But in a modified form (nurturing the rational independence and critical capacities of each learner) it has also influenced thinking and practice in primary and post-primary education throughout most of the twentieth century. The Enlightenment's educational ideals have also had their opponents however, and in our own day one of the most incisive of these has been Alasdair MacIntyre, at least in his writings other than Dependent Rational Animals (1999a). MacIntyre's view that the 'Enlightenment project' was a mistake was given eloquent articulation in his book After Virtue (1981) and the educational manifestations of that standpoint appeared in writings such as 'The Idea of an Educated Public' 
(1987), the concluding chapters of Whose Justice? Which Rationality? (1988) and Three Rival Versions of Moral Enquiry (1989), and more recently in his essay 'Aquinas's Critique of Education: Against his Own Age, Against Ours’ (1998).

More recently still, in his interview with Joseph Dunne in this journal (MacIntyre and Dunne, 2002), MacIntyre has articulated his most challenging arguments to date on education as a human undertaking. Among the more conspicuous claims MacIntyre makes in this interview are the following four: that teaching itself is not a practice (p. 5); that the life of a teacher is not a specific kind of life; that teaching is never more than a means; that the philosophy of education is not a distinct area of philosophical enquiry (p. 9). Claims such as these can hardly fail to sound perturbing to any teacher to whom teaching is more than a casual or occasional occupation, and who thinks seriously about the nature, the scope and the justification of that occupation. ${ }^{2}$ In this essay I want to call into question just such claims and to show that when education as a human undertaking is properly understood and carried on, it can be seen to be a singular instance of a practice with an integrity of its own. Thus the realities to be encountered in the following exploration are likely to be understood quite differently than they are in MacIntyre's thinking. My main purpose here is of course shared by other contributors to this collection, most of whom include some close readings and criticisms of MacIntyre's texts from the first edition of After Virtue (1981) onwards. In my own investigation, however, I propose to take a somewhat different path, one from which MacIntyre's works will not be absent, but along which other figures, most notably a largely forgotten Socrates of Athens, will feature more prominently.

\section{ELUDING A MISLEADING SPECTRUM}

To get the investigation under way, I want to review two broadly-conceived characterisations of teaching that remain prominent in the educational discourse of our own day: teaching as 'a vocation' and teaching as 'just a job'. To claim that teaching is a 'vocation' is to share a standpoint with those who occupy the opposite end of a spectrum from those who claim that teaching is 'just a job' much like other jobs, with a certain set of skills to be mastered and performed. A more sophisticated version of the 'just a job' view might assert that teaching is a 'multi-skilled' job, even 'a profession', while avoiding any concessions to the 'vocation' standpoint. The 'vocation' concept, for its part, has a long ancestry in the history of Western education, associated chiefly with the prominence of church influences in that history. It carries strong connotations of service given for a loftier purpose than monetary reward and it is also linked with ecclesiastical requirements of obedience to higher authority. An adversarial or resistant stance towards such higher authority, though nowadays usually a secular authority, frequently underlies the 'just a job' view. This is especially so in the campaigns of many teachers' unions, where refinements of the 'multiskilled' view are much in evidence. 
To argue the case for teaching and learning as a way of life however, as I am keen to do here, is to attempt something that is deliberately bold, though bold in a way that is hopefully circumspect rather than rash. In short, it is to discard both the 'vocation' concept and the 'just a job' concept and to set aside the entire spectrum of positions that might lie between them. ${ }^{3}$ It is to call into question any view which holds that teaching is essentially the kind of work, multi-skilled or otherwise, that is to be decided in all essentials by a body of superiors and carried out by subordinates on the instructions of that body. Second, it is to bring learning centrally into the picture: to allow a view to emerge that gives due recognition to the experience and the responsibilities of human learning in any adequate understanding of teaching. These points suggest that to make teaching one's way of life, properly speaking, is to make an occupational commitment to a form of action that has an authority of its own and responsibilities of its own, and to understand that these two features constitute the integrity of that way of life. ${ }^{4}$ What is fundamentally at issue in this suggestion is that such integrity-its proper elucidation, its recognition, its safeguarding, its promotion-is the crucial matter. This recognition of teaching as a specific way of life with its own integrity is more important, for instance, than the recognition that one is a teacher of subject $x$ or subject $y$, of children or of adolescents.

The historical and cultural contexts in which teaching and learning inescapably take place are not being forgotten or obscured by this suggestion. Neither are the powerful interests that have historically denied to the conduct of teaching and learning the integrity that has just been mentioned. In fact it is part of my argument to stress the point that the enduring responsibilities that distinguish teaching as a way of life may sometimes be in tension with the established forces of power and influence. The occupational commitment referred to in the previous paragraph is then a double commitment: to teaching and learning as a human practice, not just as a repertoire of competencies to be mastered, transmitted or shared. What is involved is not merely a fluency in skills and strategies of communication but also something qualitatively different: a commitment to teaching and learning as a distinctive way of being human in a world that is now one with an unprecedented plurality of lifestyles, value orientations and careers.

In what has been sketched here there are some intimations of what a fuller elaboration of teaching and learning as a way of life might look like. But what has so far been only suggested must now be explored in some detail, though in a chapter-length study the exploration must necessarily be introductory rather than comprehensive in character.

\section{THE EXAMPLE OF THE SOCRATIC}

Possibly the best exemplar of teaching as a way of life in the history of Western civilisation has been Socrates of Athens." By 'Socrates of Athens' I am keen to identify the historical Socrates and to distinguish him 
as clearly as possible from the placeless person called 'Socrates' who acts mainly as an ingenious device for Plato's views in the middle and later writings of Plato. The historical person Socrates, to the best of our knowledge, left no writings of his own to posterity. Yet we ${ }^{6}$ get some intriguing insights into his life and work in Plato's early dialogues, and in the writings of a few other Greek contemporaries. But in what meaningful way could such an archaic figure (469-399 BC) have any relevance to teaching in the twenty-first century? Indeed the question itself may sound a little quaint, especially in view of the international mobilisation of energies at present in harnessing communication technologies to new demands and new goals for education and training.

Where teaching is to be understood primarily as a means to an extrinsic end, or as a body of techniques and skills in the service of an enterprise of which teachers themselves are not the primary authors, it is no surprise that issues such as the significance of Socrates will be seen as unimportant. Such an instrumental view of teaching however casts it as the work of functionaries, no matter how camouflaged this reality might be, no matter how highly paid such functionaries might be, and regardless of whether they teach in nursery schools or in university graduate schools. ${ }^{7}$ Teachers, on this view, remain essentially underlings, as distinct from uncoerced participants in an occupation with its own authority and its own forms of responsibility. It is only on some such instrumental view that MacIntyre's claim that 'teaching is never more than a means' can gain purchase. And where one's work consists essentially in carrying out routinely and effectively a series of duties laid down from above, it is largely irrelevant to speak of sources that might inspire that work and its conduct as a distinctive way of life. In fact it is largely beside the point to speak here of education as a human practice: i.e. as a form of purposeful action with goods and virtues internal to itself that it seeks to sustain and develop.

To suggest, by contrast, that teaching might indeed be an occupation with an authority of its own, and with responsibilities that are distinct, is to bring the example of Socrates of Athens centre-stage; not as someone with the right answers for his own day or ours, but as a singular kind of inspiration. It is to question the appropriateness of the means/ends distinction where the experience of teaching and learning is concerned. It is to announce the radicalness of the view that teaching is a way of life. One might be tempted in this connection to proclaim Socrates the 'patron saint' of teaching as a way of life, and thereby distinguish that way of life from any conception of teaching as a set of skills and techniques that one might employ or deploy for a range of extrinsic purposes. But whatever the merits of such a move, it tends again towards a 'vocation' conception of teaching and makes Socrates a figure of reverence. And since neither saintliness during his life nor sainthood after his death sit well with Socrates, the temptation can happily be set aside. This opens the way then for a more unimpeded engagement with the human Socrates and his thinking.

Some remarkable insights come to light when the figure of Socrates as a teacher is no longer eclipsed by the 'Platonist' Socrates of much of 
Western philosophy, or when access to his work is no longer beclouded by a reverential or otherwise uncritical embrace of 'Socratic method'. Arguably the most important of these insights is that behind all the apparent inconclusiveness of so-called Socratic dialogue lies a singular kind of conviction on the part of Socrates himself. Related to this realisation is the recognition that anything described as 'Socratic method' remains a vacuous notion in the absence of an understanding of the kind of conviction in question. Once one becomes aware of what this conviction is, moreover, one can see it in action in the educational encounters of the early Dialogues, for instance Gorgias, Protagoras, Euthyphro, or Book I of the Republic. In these works, the Socrates portrayed resembles most likely the real Socrates who engaged in such encounters in the houses and public places of ancient Athens. ${ }^{8}$ Familiarity with the nature of this conviction also enables one to recognise the kind of educational progress that it can accomplish, despite the apparent inconclusiveness of these encounters. Indeed, as we might see a little later, in just such inconclusiveness might lie particularly promising possibilities.

But these early writings of Plato do not make explicit the nature of this curious conviction of Socrates, and as a result the arguments in early works like Gorgias and Protagoras, for instance, can give the reader the impression that they end up much where they started. More vexingly, they may lead the reader to conclude that Socrates is leading his partners in enquiry around a maze for his own enjoyment, or to confound them. Of course such vexation contributed in no small way in bringing Socrates to court on a double charge of impiety toward the Gods and corruption of the youth of Athens. It is his dramatic courtroom defence, recalled in the early Plato's short work Apology, that explicitly reveals the convictions that informed Socrates' life, most notably his work as an educator. Socrates understood well that the pronouncement of the oracle at Delphi that 'Socrates is the wisest of men' provoked much resentment among the sophists, whose standing as the most prestigious of teachers it publicly confronted and in some ways undermined. Socrates now proceeded to tell the jury-of 501 fellow citizens - that the significance of the oracle's declaration was very different from what the sophists, and many other Athenians, were disposed to believe:

Real wisdom is the property of God, and this oracle is his way of telling us that human wisdom has little or no value. It seems to me that he is not referring literally to Socrates, but has merely taken my name as an example, as if he would say to us 'The wisest of you is he who has realised, like Socrates, that in respect of wisdom he is really worthless' (Apology, 23).

On the face of it, it might seem that this was a counsel of despair for all human teaching and learning, not just that carried on by the sophists. For Socrates however it was just the reverse. He set out, he explains to the jury, to disprove the oracle's declaration and his efforts in this pursuit led him to engage in questioning debates with the most highly acclaimed 
experts of Athens. Socrates was taken aback at first to discover that the expertise claimed by many of the leading lights of Athenian culture was often more counterfeit than real. As his debates with these 'authorities' proceeded, however, Socrates discovered the real significance of learning, as it became his distinctive way of life. Among the most important lessons he learnt was that limitation, partiality, lack of finality and not least fallibility are probably inescapable features of all human efforts to understand and to know.

This sheds a crucial light on his encounters with young Athenians, and indeed with their elders. In these encounters Socrates' questioning can now be seen to be following pathways that he had already navigated to a greater or lesser extent in his own mind, but without having found answers that were conclusive beyond doubt. So they were pathways on which he was invariably keen to venture afresh with others. Through such venturing some new insights might be forthcoming, some previous wrong turnings or dead ends might be brought to light, some modest progress might be made towards truth.

The reference to truth here is crucial, but not truth in the sense of a destination at which one arrives with certainty or finality. Unlike the 'Socrates' of Plato in his middle and later writings, truth remains for Socrates of Athens something towards which even the of best human efforts can probably never achieve more than to be on the way. To make some progress toward truth, on this account, is to become aware of the provisional status and fallible character of what even the best investigations have yielded: i.e. those fruits of enquiry and argument that can be sustained in the face of the best available criticism, and not just local criticism. Likewise, it is to come to appreciate, through reflection on the fruits of discovery itself, that final truth, or absolute truth, is probably beyond measure or encapsulation by humankind. ${ }^{9}$ Here lie the reasons for Socrates' conclusion that the final truth, or 'real wisdom' as he calls it, is divine rather than human. And this means that the more wise that humans become through their best collective efforts, the more appreciative and critical they might also become in their engagements with inheritances of learning. Yet by the same token, the more modest they might become about the pretensions of human knowledge, even at its most impressive.

In the example of Socrates of Athens we can discern a kind of thinking that involves a distinctive stance towards teaching and learning. More precisely, we begin to understand that stance as an enduring educational disposition, one that contrasts strongly with the more coercive dispositions that were to prevail throughout most of the history of Western education. Bearing in mind Pierre Hadot's distinction between philosophy as a professional theoretical endeavour and philosophy as a way of life (Hadot, 1995), such a reflective-cum-practical disposition might rightly be described as a distinctive kind of philosophy. This is a kind of practical philosophy that one might properly call the philosophy of education, or at least one clearly recognisable form of the philosophy of education. Such philosophy is foreign to metaphysics - understood as that long and varied search from Plato's later works onwards for an authoritative and 
conclusive account of all of reality. It is no less foreign to rationalist epistemology and its various 'scientific' offspring - understood as that search of more recent centuries for stable and certain foundations for all of knowledge. Yet the full educational significance of this Socratic kind of philosophy comes to light only when one recognises that the points that have just been made about truth and fallibility refer not only to truth as statements and propositions. More importantly they refer to truth as an orientation for how one ought to live one's life. And it is here that the elusive yet beckoning character of truth, as something that for humans remains a defining, unfinishing search, comes into its own.

We shall return later to examine the import of these arguments for teaching and learning in our own day. At this point however it is instructive to review a very different outlook on teaching and learning that now enjoys prominence in Western civilisations. This is a view which denies to education as a practice much of what MacIntyre's claims deny it, albeit for different reasons. It is a view that owes little to Western or to any other cultural inheritances. But it is a view that is still keen to claim, possibly for expedient reasons, some kind of kinship with such inheritances. It is a stance that has no connections with the tradition of Socrates that we have just explored and that has also effectively severed connections with the metaphysical traditions that eclipsed and superseded the Socratic in Western Christendom, and in the subsequent history of Western education until the modern age. ${ }^{10}$

\section{LEARNING AS STRATEGY, PERFORMANCE AS A WAY OF LIFE}

In what is now commonly called a 'learning society' or an 'information society,' learning achieves an importance that is without precedent. This is largely a strategic importance, however, frequently linked to commercial purposes or to the goals of national economic and social policy. In this macro-perspective, predominant among policy makers in an age of globalisation, learners come to be regarded as important human resources in an international competitive market. The purposes of teaching, the contents of learning and the experienced quality of education become accordingly recast. Teaching itself becomes increasingly characterised as a set of skills: significantly, skills that can effectively be itemised and increasingly carried out by the electronic operations of 'e-learning'. Teaching as a human practice thus recedes in this perspective, or is nudged aside, from the frontiers of learning and its advancement.

From the point of view of the foregoing arguments, what is particularly striking about the official literature on 'the learning society' is the absence of a cultural emphasis. This is most evident in the 1996 White Paper of the European Commission titled Teaching and Learning: Towards the Learning Society. This is a landmark document which has purposely sought to dissolve the distinction between education and training and which has both shaped and reflected the tenor of recent educational policy in most of the countries of the European Union. ${ }^{11}$ It has also spawned a 
new genre in official educational literature ${ }^{12}$ and has led to successive waves of financially backed initiatives that are designed to give direction to national education policies in an expanding EU. How learning itself is to be conceived and pursued in 'the learning society' becomes clear from the five main goals of the White Paper:

(a) promoting the new knowledge needed for accelerated technological advance;

(b) bringing schools and business closer together;

(c) combating social exclusion;

(d) achieving a communicative proficiency in three EU languages;

(e) treating capital investment and investment in training on an equal basis.

The first, second and last of these are clearly goals of economic policy. The third, combating social exclusion, is primarily a goal of social policy. It could also of course be an imperative of educational practice. But as such it would have to be concerned with issues of justice and educational benefit in the conduct of teaching and learning, not just with matters of access and retention in schooling. The fourth goal, communicative proficiency in three EU languages, is conceivably an educational one, but this depends on whether proficiency is being promoted for reasons that are primarily for the learner's cultural benefit or for the sake of facilitating commerce between different countries in a common market. ${ }^{13}$ That the latter is more likely to be the case is evident from the market-inspired thinking and the individualist recommendations of the White Paper as a whole. The individualist note is set in the Introduction, in declarations like the following:

The level of skill achieved by each and everyone will have to be converted into an instrument for measuring individual performance in a way which will guarantee equal rights for workers as far as possible (p. 17, emphasis in original).

and

Everyone must be able to seize their opportunities for improvement in society and for personal fulfilment, irrespective of their social origin and educational background (p. 17, emphasis in original).

Despite the references to rights, equality and social inclusion, there is a serious neglect here, and elsewhere in the document, of the connection between public education and the question of how one might best live as a citizen. But with a few notable exceptions-such as the Delors report of 1996 commissioned by UNESCO, Learning: The Treasure Within-there is a notable absence in the official 'learning society' literature as a whole of the intellectual and spiritual concerns that, for better or worse, were prominent throughout most of the history of Western education. ${ }^{14}$ But pertinent as these points of criticism might be, to accept them as an 
adequate analysis of the new European educational policy context is to overlook something more important. This more important insight is that the question of the relationship between learning and how one ought to live is already answered in much of the new official discourse on the learning society. That answer is all the more effective for being implicit. To say that this new international discourse relegates the more traditional cultural and spiritual purposes of education may well be correct. But this analysis still falls short of the heart of the matter. It fails to appreciate that these purposes have effectively been displaced and that a new creed, if one may still use a religious idiom, has been installed in their place. This creed promotes a new doctrine of uniformity and regards publicly-funded education as one of its key vehicles. At first sight this might seem a strange claim to make of an increasingly plural and secular age, so some explanation is called for.

Writers such as Jean-François Lyotard, in their analyses of 'the postmodern condition' of advanced industrial countries, devote much attention to what is called the criterion of performativity-i.e. 'the best possible input/output equation' (The Postmodern Condition, 1984, p. 46). This criterion, Lyotard and others argue, has largely superseded the more traditional demands of justification, or 'legitimation', in public undertakings as well as in private-sector business. As a basis for purposeful action, it has also progressively displaced large-scale movements ('metanarratives') of a political, philosophical or religious kind, which in earlier times sought to win the minds and hearts of multitudes. On Lyotard's view, education has fallen victim to 'the predominance of the performativity criterion' (p. 47).

Whether Lyotard is fully right on this matter we will consider a little later, but it can scarcely be doubted that, as a secular and mercenary credo, performativity constitutes a new uniformity on the rise. It redefines questions of quality as questions of indexed quantity. It pervades the arenas of public debate-in business, in politics and not least in education-with ever more elaborated 'performance indicators' and operationally defined 'competencies', to the neglect of more adequate and discerning appraisals of pertinent achievements. It extends its domain by its coercive power to harness moral energies to goals of pragmatic effectiveness, as distinct from summoning those energies to accomplishments of a qualitatively richer kind. ${ }^{15}$ It tends to deprive accountability of its more healthy purposes and to re-establish it as a legalistic and increasingly an adversarial matter. In these and other ways it progressively colonises the cultures of work, and of human effort more generally. It promotes an ethos in which values connected with power and money secure the more advantageous standpoints to make claims on the commitments of those who fall under its rule. On this analysis it becomes clear how the reign of performativity takes over, by the back door as it were, some of the more important questions of how one's life is to be lived, not just how one's occupation is to be practised. It thus attains a position of influence comparable to that enjoyed by institutionalised religion in previous generations. 
In such an ethos, one can readily understand why many teachers might wish to regard their work as 'just a job', or as a set of skills and techniques whose application does not involve any strong commitment of one's heart and mind. With its reassuring air of everyday sanity, however, such a rationalisation evades the more embarrassing disclosures provided by a more perceptive self-understanding. Any one of a range of current-day occupations might serve to illustrate this point, though perhaps none more unhappily than teaching. For to acknowledge the realities of teaching as a way of life in circumstances governed by performativity would be to admit that it was a menial way of life, servile now not to ecclesiastical authorities but to their managerially-minded secular successors. In short, then, unless one begins with an incisive and robust conception of teaching as a way of life with an authority derived from its own integral purposes, one has already adopted a privative, even a defeated, standpoint. One has acquiesced in the view that what teaching and learning are to attempt and achieve are matters in which the discourse of teachers and the lore of teaching traditions are not of primary importance. One has allowed this primary importance to pass into the hands of official bodies whose commands are to be followed, not questioned. Unwittingly or otherwise, this is to turn one's back on the conviction that teaching and learning as a way of life might constitute one of the worthiest ways of being human.

These points stress the necessity for examining now what a robust, a defensible and a promising conception of teaching as a way of life might look like in the present age, and how its own authority might be exercised in practice. This will be attempted in outline in the two final sections. The first will concentrate on what such an understanding of teaching must confront and the second will be concerned with the more constructive question of its inspirations for practice.

\section{BEYOND POWER AND PERFORMANCE}

From what has been reviewed already we can see that teaching as a way of life receives its distinctive character from its inherent relationship to learning as a human undertaking, and from the significance of this more inclusive undertaking for how life is to be lived. But if one is to regard learning primarily as an instrument of progressive mastery over people and things-whether mastery of a technological, or economic, or administrative-political kind-then teaching will be seen primarily as the means by which the domains of such mastery are to be extended. In medieval Christendom such a view of teaching and learning - as an instrument of theological dominion-was common, but not universal. It made possible, purportedly for spiritual purposes, a pervasive ecclesiastical control of education. This centuries-long control was decisive moreover in establishing a widespread view that teaching as an occupation derives its warrant not from any integral purposes associated with learning and truthseeking, but from some higher authority that has secured the power to 
decree its own truths decisively and to enforce its own way wherever serious learning is to be undertaken.

The totalitarian régimes of the former Eastern-bloc countries provide a good example of how, during the twentieth century, such a custodial conception of teaching and learning received a new and vigorous incarnation. But to claim that the separation of powers of church and state in modern democracies, or the decline of Eastern communism, makes the danger of custodial conceptions of learning a thing of the past is to overlook something crucial. For while religious bodies have increasingly become voices for the disadvantaged and marginalised in Western societies, the authoritarian seats they have vacated have often been taken over and transferred to a more secular court. The ministries of education in Western democracies have, more often than not, embraced one or other variant of a traditional custodial view and tailored it to their own purposes. ${ }^{16}$ That is to say, in either blithe or calculated disregard of urbane democratic educational thought-like that of Dewey for instance-they have presumed to view public education chiefly as part of the machinery of political power.

We have already seen the fruits of this disregard and presumption when we explored the essentials of performativity, the new credo of a postreligious age that redefines questions of qualitative purpose as questions of quantifiable performance. This is not to suggest however that qualitative issues in education are thereby abandoned. Rather it is to emphasise that they now receive their significance not so much from their intrinsic educational merits as from their effectiveness in accomplishing, or 'delivering', the goals of social and economic policy laid down by governments. This shift in educational thought and practice tends to reduce inheritances of learning to a kind of raw material for fuelling higher levels of measurable performance. Less obviously, it also disfigures the concept of justice in education. Justice-including related issues like inequities in learning entitlements and in treatment-loses here its proper significance for the daily practices of teaching and learning. For it is here in these daily contexts that considerations of needs and rights are present in the most pressing and practical way. Through such disfigurement the notion of justice becomes effectively redefined as a functional element of a macro-economic undertaking and thus its ethical challenges in the faceto-face encounters of teachers and learners are relegated, if not obscured. If, for instance, one asks why 'combating social exclusion' has been made such a major educational goal, one can hardly fail to be taken aback by the answer that Lyotard's analysis of the interplays of power and performativity gives to this question:

Within the framework of the power criterion, a request gains nothing in legitimacy by virtue of being based on the hardship of an unmet need. Rights do not flow from hardship, but from the fact that the alleviation of hardship improves the system's performance . . In this sense, the system seems to be a vanguard machine dragging humanity after it, dehumanizing it in order to rehumanize it at a different level of normative capacity 
... Such is the arrogance of the decision makers - and their blindness

(The Postmodern Condition, pp. 62-63).

Notwithstanding the chilling revelation in Lyotard's logic here, to go all the way with this kind of analysis would be to conclude that the world's most technologically advanced countries have become totalitarian technocracies: that no room is left for either intellectual or practical action, unless that action is manifest as one or other form of performative effectiveness-i.e. of coercive power. The indiscriminate nature of the conclusion itself is evident, but a brief comparative example should make its pertinence to teaching and learning clearer. If one were to apply this kind of analysis for instance to pre-modern societies, the conclusion would be that they were authoritarian theocracies in which constructive action inspired by motives other than theocratic ones would be forestalled or eliminated. Although such an analysis can be supported by much historical evidence, it also ignores any conflicting evidence which would deny its claim to be a definitive one. For instance, if this analysis were the full story, many of the major landmarks in the history of Western learning would have been successfully frustrated, such as the work and influence of Erasmus, of Copernicus and Galileo.

The sweeping character of some of Lyotard's conclusions should not however take from the point that his analyses furnish incisive and sobering insights about movements and trends that have become decisive in late modernity. In particular, his explorations of performativity reveal how insidiously the rationality that conceives and carries out major public enterprises can become altered, and in a way that attenuates what notions like quality and justice are to mean. And once these shifts are brought to light from behind a haze of international 'democratic' pronouncement, and are made available for critical consideration, the enormity of that redefinition begins to sink home. Teachers, for instance, will see that, when stripped of its populist or other plausible attire, there is little in the creed of performativity that is worthy of their sense of occupational commitment. That is of course unless they are content-from aspirations of individual preferment or for other reasons-to view themselves as agents or functionaries of such a creed. The same argument applies, though in somewhat different ways, to school managements, to students and to parents of school-going children.

Champions of a 'performativity' view of occupational commitment are normally in positions of political, or commercial or administrative leadership. It is important to add that, for the most part, they are anything but malevolent or wilful people. As 'civilised' human beings, they are unlikely to regard themselves as advocates of anything other than ordinary goals such as 'higher standards', or 'year-on-year growth', or 'increased competitiveness'; all of which are now commonly taken to be self-evidently salutary goals, and conducive to healthy institutional life in advanced industrial society. Terms like these feature increasingly moreover in contemporary discourse about 'best practice' in most occupations. To the extent that such trends become the prevailing pattern in educational 
thought and action, however, they lose sight of what is distinctive about teaching and learning as a way of life. That is to say, they obscure the point that teaching, in the fullest and most enduring sense of the word, is essentially a commitment to the more worthy fruits of learning itself as a way of being human.

\section{TEACHING AND LEARNING AS AN ACTIVE RELATIONSHIP}

With these remarks we have come to the point where the character and significance of teaching as a way of life might be set forth more concretely. From what has been explored already it is clear that something of a Socratic kind of inspiration is crucial to this way of life. This is not of course to argue for any return to the past, or for any incorporation of fourth-century BC Athens into the historical and cultural realities of the twenty-first century. Rather it means, first of all, to attend with an incisiveness of mind and an openness of heart to inheritances of learning. It also means trying to discern in these inheritances what is most deserving of one's convictions and sustained practical efforts when it comes to making a sincere commitment to teaching as a human occupation, and more generally to education as a human undertaking. To put the matter in this way is to emphasise a number of important matters. To begin with, one recognises here that one's work as a teacher is never without a philosophy of education of one kind or another, whether explicit or implicit. ${ }^{17}$ Such a philosophy moreover is invariably informed by a range of inherited influences, including ones of recent or even contemporary origin. Performativity itself counts as such a philosophy, whether actively embraced as a credo, or unreflectively manifested in the energetic pursuit of one's work, or resentfully endured as an everyday burden. Recalling our earlier discussion, the philosophy of education-as a reflective-cumpractical discipline_might begin its fruitful work with a questioning of such inherited 'philosophies'.

More critically perhaps, a Socratic understanding of teaching and learning highlights the point that every philosophy of education involves not merely a 'what'-i.e. a specific body of aims and contents. It also involves a 'why'-i.e. some sense of purpose and rightness, coherent or otherwise. Finally, it involves a 'how'-i.e. a range of attitudes, dispositions and practices by which the aims are faithfully or less than faithfully pursued. To regard teaching as a way of life with its own claims to worthiness is to stress that the 'what', the 'why' and the 'how' need to be made explicit and justified. In this connection it is important to note that all three converge naturally when teaching and learning are understood not as discrete actions but as a relationship entered into from different cultural perspectives by teachers and pupils. Again, the example of Socrates proves especially illuminating. It provides not so much doctrines or prescriptions, but some fertile ideas for understanding the 'why' of educational purpose, the 'what' of educational substance (i.e. voices of tradition), and the 'how' of teaching and learning (i.e. active, searching engagements with these voices). 
Socrates conducted his work as an ever-renewed invitation to his students to participate in a jointly undertaken enquiry. For the teacher this involves becoming, in some degree at least, a practical philosopher of the kind described above. Where the daily practices of teaching and learning are concerned, it means giving an attentive ear to the many and different voices of tradition, in order to elicit most promisingly what is addressed to human imagination and sensibility by these voices. Second, it also involves, on the teacher's part, developing a well-attuned ear for the responsive capabilities of the students in relation to these voices. Third, it involves refining one's range of communicative capacities in order to elicit these responses from students and to nurture them to a self-critical and an increasingly fluent engagement with these voices. It is important to point out here that any particular subject, for instance history, or music, or mathematics, might itself comprise a variety of voices, even disparate or refractory ones. The 'goods' pursued by the teacher then are not abstract 'goods' of mathematics or of history, or of science. Rather, teaching as a way of life is constituted by the complex practice of bringing about and sustaining relationships of learning in which the voices of history, of poetry, of science, etc. are enabled to speak, and to get a critical yet a generous response from learners. Other than the intrinsic benefits of learning realised by such active practices-enablements of mind and of heart-it is difficult to imagine what the 'goods' of mathematics, or history, or science, or any other field of study, might be.

And of course for Socrates, teaching sometimes involved the critical use of dramatic devices like irony, baiting, mock flattery and occasionally ridicule. A study of the early dialogues of Plato (e.g. Gorgias, Protagoras, Euthyphro, Republic Book I) shows however that these devices were availed of only where the arrogance, or conceit, or petulance of one or other participant was interfering with the effort to get an unhindered enquiry under way. The more adversarial of these arts seem to have been strangers to Socrates' actions with earnest learners.

Reflection on these points - and not least the contrast with the skills and techniques deployed by the sophists-explains the ironic purpose in Socrates' refusal to describe himself as a teacher. It also brings to light the significance of his remark (in Gorgias 521) that his work was in fact the 'true political art'. A refusal of a similar kind might safeguard the philosophy of education from becoming an ideology, or a technology, or a theoretical activity lacking a coherent view of its own more important purposes: namely those of clarifying and refining, safeguarding and promoting the 'true political art' of teaching and learning.

In making Socrates of Athens central to this essay I have tried to evoke the kinds of attitudes, dispositions and actions that constitute this 'political art': an art that could scarcely be more different from the power plays of conventional politics. The practical thrust of such attitudes and dispositions is evident in their interweaving character, or in the artificiality of drawing sharp distinctions here between attitude, disposition, and action. For this reason it is more accurate to speak here of dispositions to action. As the fruits of a practical kind of philosophical thinking, such 
dispositions to action are to be clearly distinguished from religious conceptions of obedience and its various requirements, and from political conceptions of loyalty to party or leader. Their specific character-as sketched below-is central to identifying teaching as a distinctive practice, or more generally as a distinct way of being human. This is not of course to suggest that one's every waking moment is dedicated to this practice. It is to suggest, however, that the dispositions to action that characterise teaching as a way of life might also make available, in an unforced way, possibilities for a rich, imaginative social and cultural life on a teacher's part: possibilities that might otherwise lie beyond one's horizon of awareness.

Such dispositions to action are too numerous to provide an exhaustive survey here, but a review of the arguments made to this point would call for the inclusion of the following in any summary: an alert appreciation that 'real knowledge is the property of God' and a corresponding consciousness of the inherent limitations of even the best of human enquiries; an acknowledgement of both the modesty and the everemergent prospects that befit learning as an unfinished and unfinishable undertaking; a realisation that the most promising and most defensible purposes of teaching are to be found in connection with this larger undertaking; the self-critical insight that teaching is itself a form of learning-anew with others, where the teacher acts as listener, questioner, instructor, guide and as a responsible and caring leader; the awareness that differences in capability, in aptitude and in sense of identity complicate but also enrich what is to be understood as equity and appropriateness in educational experience; an appreciation of the point that in a genuine community of learners a distinctive ethos arises in an unforced way; a critical awareness that knowledge as assertive mastery, or as individualist power, or as coercive prowess, works-behind the scenes as it were-to undermine such an ethos. This is just an initial sketch of some dispositions to action, or practical virtues, that might distinguish teaching as a practice, but it serves nevertheless to show that what are called 'skills', 'habits' and not least 'methods' belong to teaching in a way that is much more intricate than the normal use of these terms might suggest.

In conclusion, it hardly needs to be stressed that the effort to experience teaching as a way of life means joining a recurrent if not continual struggle: a struggle between higher forms of human freedom and influences which continually threaten that freedom with overt or more subtle forms of captivity. Success in such struggle is not an all or nothing affair. It is more a matter of degree, of fluctuating degree at that.

Teaching as a way of life then is neither sainthood nor persecution, though it may not be without its moments of blessed inspiration or infernal turmoil. Neither is it to be confused with asceticism or priesthood, which may properly be regarded as vocations. Rather it is a singularly conversational way of being human in a world that is 'human, all too human', as Nietzsche once put it; a world that would be bereft of something incalculable without the way of life that we have been examining and the kinds of convictions that inspire it. 


\section{Correspondence: Pádraig Hogan, Education Department, National University of Ireland Maynooth, Maynooth, County Kildare, Ireland Email:phogan@may.ie}

\section{NOTES}

1. Throughout most of this Western history, the Christian church, and later the denominational churches, acted as custodian and enforcer of uniformity in what was to be believed and what was to be taught. As W. Boyd and E.J. King put it in their book The History of Western Education, 'The clerical monopoly of education established in the age of transition from the ancient world to the modern lasted for more than a thousand years, and its effects on the intellectual life of Europe were tremendous. The most obvious result was the general restriction of learning within boundaries fixed by the Church's interests and doctrines' (p. 101). It would be a mistake however to conclude from this that the Church was essentially a malign force.

2. Apart from the claim that teaching is never more than a means, there is of course a sense in which MacIntyre's claims about teaching are not controversial, especially if one includes as teachers the parents and others from whom young children learn (or fail to learn) crucially important things before they ever set foot in school, and indeed after they finish their schooling. On this more informal kind of learning, MacIntyre has many illuminating points to make in his book Dependent Rational Animals (MacIntyre, 1999).

3. Notwithstanding the unproblematic everyday use of the term 'the teaching profession' many construals of teaching as 'a profession' are ill-founded attempts to build something on such middle ground. By following a common path of taking medicine or law as the exemplars of 'profession' such attempts often run up against differences (e.g. nature of professional-client relationship, terms and conditions of employment, capacity to charge fees) that make the comparisons more burdensome than helpful and that in any case detract from an understanding of what is most distinctive and positive about teaching as a practice.

4. In putting the matter in this summary way, I am aware that it would take more than a few pages to make fully explicit the connections that underlie my characterisation. In lieu of these absent pages let me say that I am indebted here to Hannah Arendt's thinking on the importance of action amid 'the frailty of human affairs' and to Paul Ricoeur's arguments on action as an 'autonomous discipline', or more specifically, 'the originality of the tie between action and its agent'. See Arendt, 1958, ch. 5; Ricoeur, 1992, pp. 113ff.

5. This might be disputed by those who believe that this distinction should go to Jesus Christ. Although a close reading of the New Testament Gospels provides some insights into the remarkable accomplishments of Christ as a teacher, the picture that emerges is intermittent and incomplete. The portrayal of Socrates in the early dialogues of Plato, though also far from complete, is more informative than that of Christ as teacher in the Gospels. It also contains many parallels with the Gospels' depiction of Christ as a teacher. Not the least of these is the enigmatic suggestiveness that underlies the actions of both.

6. It may be advisable at this point to say something about my use of the first person plural- 'our', 'we'-in these sentences and elsewhere in the essay. In using 'our' and 'we' I am aware that such usage can be exclusionary, or even patronising - as for instance where the 'we' is ostensibly universal in scope but tacitly refers to some select group, such as, for example: 'European intellectuals', or 'Western liberals'. So to clarify matters, the use of the first person plural in this essay potentially includes anyone and everyone who cares sufficiently about education to give some serious thought to issues of teaching and learning and to confront preconceptions of their own (incl. 'my own', 'our own') that might come to light. The arguments put forward in the essay are recognisably Western, of course, though they seek engagement with both Western and non-Western currents of thinking.

7. The view that teachers are no more than functionaries is one that J.F. Lyotard seems to take as an established fact in his influential work The Postmodern Condition, Lyotard, 1984.

8. The difference between the historical Socrates who is imaginatively recreated in Plato's early writings and the Socrates used as a literary device in Plato's middle and later writings is a theme of recurrent debate and research. For instance, two works from Plato's middle period, Meno and Symposium, draw intriguing pictures of Socrates as an educator, but also as enunciator of central 
themes of Plato's metaphysics that were very unlikely to be held by the real Socrates of Athens. For this reason I have excluded them from the clearly definable early group that includes Protagoras, Gorgias, Euthyphro, Apology and Republic Book 1. The most notable recent study on the distinction between the real Socrates and Plato's metaphysical Socrates that I have come across is Socrates: Ironist and Moral Philosopher by Gregory Vlastos (Vlastos, 1991). This book draws the distinction in a particularly clear way and supports its arguments with a comprehensive study of the works of Plato.

9. Reference to 'final truth' and 'absolute truth' here does not, of course, mean the final truth about empirical questions like 'Who planned the assassination of John F. Kennedy?' or 'How many Dublin pubs are mentioned by name in Joyce's novel Ulysses?'

10. In jumping to our own time I am of course leaving out some of the most interesting periods in the history of Western Education, namely the Middle Ages and the era of the Enlightenment. I have attempted some explorations of these in chapters 2, 3 and 4 of The Custody and Courtship of Experience: Western Education in Philosophical Perspective (Hogan, 1995a).

11. On the significance of culture in education, the 1996 European Commission's White Paper, Teaching and Learning: Towards the Learning Society, (European Commission, 1996), declares as follows: 'The essential aim of education and training has always been personal development and the integration of Europeans into society through the sharing of common values, the passing of cultural heritage and the teaching of self reliance.' (p. 18) First, this passage ignores the distinction between education and training which has been a feature of educational discourse in most European countries since Plato and Aristotle. Second, it obscures the distinctiveness and denies the diversity of most that has been enduring in the heritages of European civilisations, while at the same time attempting to press into service European 'cultural heritage' in order to advance a new educational orthodoxy for the member countries of the European Union. The White Paper fails to acknowledge even in a minimal way the politics of identity, of recognition, and of difference, which are central to what its own argument invokes as Europe's 'cultural wealth and diversity' (p. 17). It shows no awareness of the existence of a large body of literature on these very issues.

12. Much of this literature, from 1995 to the present, can be viewed on the website of the Directorate of Education and Culture of the European Commission at http://europa.eu.int/comm/education/ index_en.html

13. I am not suggesting that the latter goal-the extrinsic commercial one-has no place in an educational perspective. It has, though less as a goal than as an unforced consequence.

14. Unlike the 1996 EU White Paper, Teaching and Learning: Towards the Learning Society, the 'Delors Report' of the same year (Delors et al., 1996) shows some serious concern for education for citizenship. Notwithstanding the point that Jacques Delors is a former President of the European Commission, the 'Delors Report' seems to have been eclipsed by the EU White Paper and its many offspring documents, where the rationale for educational policy in the countries of the European Union is concerned.

15. There are some parallels between my argument here and Alasdair MacIntyre's arguments on the good of excellence and the goods of effectiveness in ch. 3 of Whose Virtue? Which Rationality? (MacIntyre, 1988).

16. I should point out here that in my own country (Ireland), although the experience of educational reform has had its difficulties and controversies, it has also been something of a refreshing exception to the international pattern to which I have just been referring. See John Coolahan (ed.) Report on the National Education Convention (Coolahan, 1994).

17. To acknowledge this point adequately, and to face up to its manifold and challenging consequences in an intellectually honest way, is to acknowledge-contra MacIntyre in his interview with Dunne-that the philosophy of education is a recognisably distinct area of philosophical enquiry. It is also to be confronted with many demands that are distinctly different from those of institutionalised academic philosophy. 